\title{
Successful use of locally applied polyhexamethylene biguanide as an adjunct to the treatment of fungal osteomyelitis
}

\author{
Genevieve Walls MBChB FRACP ${ }^{1}$, Lisa Noonan MBChB FRACP ${ }^{1}$, Elizabeth Wilson MBChB FRACP2, \\ David Holland MBChB FRACP PhD ${ }^{3}$, Simon Briggs MBChB FRACP ${ }^{1}$
}

\begin{abstract}
G Walls, L Noonan, E Wilson, D Holland, S Briggs. Successful use of locally applied polyhexamethylene biguanide as an adjunct to the treatment of fungal osteomyelitis. Can J Infect Dis Med Microbiol 2013;24(2):109-112.

Fungal osteomyelitis is rare in immunocompetent patients and is often difficult to cure, even with optimal medical and surgical management. The authors present two cases of fungal osteomyelitis in which the common swimming pool cleaner, polyhexamethylene biguanide, was used successfully as an adjunct to standard surgical and medical treatment. Also presented is a literature review on the use of polyhexamethylene biguanide for this indication. The authors recommend that this safe and well-tolerated compound be considered as part of the treatment for fungal osteomyelitis.
\end{abstract}

\author{
L'utilisation positive de l'application locale de \\ polyhexaméthylène buiganide en plus du traitement \\ de l'ostéomyélite fongique
}

L'ostéomyélite fongique, rare chez les patients immunocompétents, est souvent difficile à guérir, malgré une prise en charge médicale et chirurgicale optimale. Les auteurs présentent deux cas d'ostéomyélite fongique dans lesquels le polyhexaméthylène biguanide, un nettoyeur pour piscine courant, a été utilisé avec succès en plus du traitement chirurgical et médical. Ils présentent également une analyse bibliographique de l'utilisation de polyhexaméthylène biguanide pour cette indication. Les auteurs recommandent d'envisager d'utiliser ce composant sécuritaire et bien toléré dans le cadre du traitement de l'ostéomyélite fongique.

Key Words: Fungal osteomyelitis; Fusarium solani; Polyhexamethylene biguanide; Scedosporium prolificans

\begin{abstract}
Cungi are uncommon causes of osteomyelitis in immunocompetent patients (1). Fungal osteomyelitis can be difficult to treat (2); the optimal management is a combination of antifungal treatment and surgical debridement (2-5), although this approach is not universally successful (2).

We report two cases of fungal osteomyelitis in which local application of the common swimming pool cleaner polyhexamethylene biguanide (PHMB) was used in conjunction with antifungal treatment and surgical debridement to achieve cure or prolonged remission. We review the literature on the use of PHMB for the treatment of fungal osteomyelitis.
\end{abstract}

\section{CASE PRESENTATIONS}

Case 1

An immunocompetent 35-year-old Samoan woman presented in 1996 with a two- to three-year history of right heel pain. There was a remote history of stepping on a needle in the late 1970s but no recent trauma. Examination revealed a swollen right heel with tenderness over the calcaneus. Plain x-rays and a computed tomography scan of the foot revealed osteomyelitis of the calcaneus.

An open biopsy was performed. Histology was consistent with chronic osteomyelitis. No fungal organisms were apparent on microscopy. Bacterial cultures were not contributory and biopsy specimens were not sent for fungal culture.

The patient was twice lost to follow-up between 1996 and 1998. In 1999 she again presented with worsening pain and swelling in the right heel. A magnetic resonance image of the foot showed multiple areas of osteomyelitis within the calcaneus with significant associated soft tissue swelling.
Another open biopsy of the calcaneus was performed in 1999 . Histology revealed necrotizing granulomatous inflammation and fungal organisms. This time, Fusarium solani was cultured. Susceptibilities were established using breakpoint plate minimum inhibitory concentrations (MICs). The organism was resistant to miconazole, itraconazole, amphotericin B and ketoconazole.

The patient was again lost to follow-up and presented again in 2004 with worsening right foot symptoms, which now also involved the ankle.

Susceptibility testing on the original isolate from 1999 was repeated. Sensititre (Trek Diagnostic Systems, USA) MICs were: amphotericin B $2.0 \mathrm{mg} / \mathrm{L}$ (resistant), itraconazole $1.0 \mathrm{mg} / \mathrm{L}$ (resistant), ketoconazole $1.0 \mathrm{mg} / \mathrm{L}$ (resistant) and voriconazole $0.5 \mathrm{mg} / \mathrm{L}$ (susceptible).

Oral voriconazole $200 \mathrm{mg}$ twice daily was started in April 2004, with distinct clinical improvement. A surgical opinion was sought. It was believed that radical debridement would leave the patient with a nonfunctional hindfoot and amputation was recommended as the only option for cure. The patient refused amputation.

During 2005 and 2006, the voriconazole was temporarily stopped twice: on the first occasion due to a period of noncompliance and on the second occasion because funding for the voriconazole had expired and there was a delay while further funding was sought. On each occasion symptoms recurred within weeks of stopping voriconazole.

Magnetic resonance imaging of the foot was repeated in 2006. This showed persistent osteomyelitis of the calcaneus and cuboid, with a mass of abnormal tissue adjacent to the calcaneocuboid joint and surrounding the Achilles tendon in Kager's fat pad (Figure 1).

An additional surgical opinion was sought in 2007. In May 2007, radical debridement of the right calcaneus was undertaken. Large amounts of infected material were excised. The wound and bone were

\section{${ }^{1}$ Department of Infectious Diseases, Auckland City Hospital; ${ }^{2}$ Department of Infectious Diseases, Starship Children's Hospital; ${ }^{3}$ Department of} Infectious Diseases, Middlemore Hospital, Auckland, New Zealand

Correspondence: Dr Genevieve Walls, Department of Infectious Diseases, Middlemore Hospital, Private Bag 93311, Otahuhu, Auckland,

New Zealand. Telephone 64-9-276-0000, fax 64-9-276-0156, e-mail genevieve.wall@@iddlemore.co.nz 


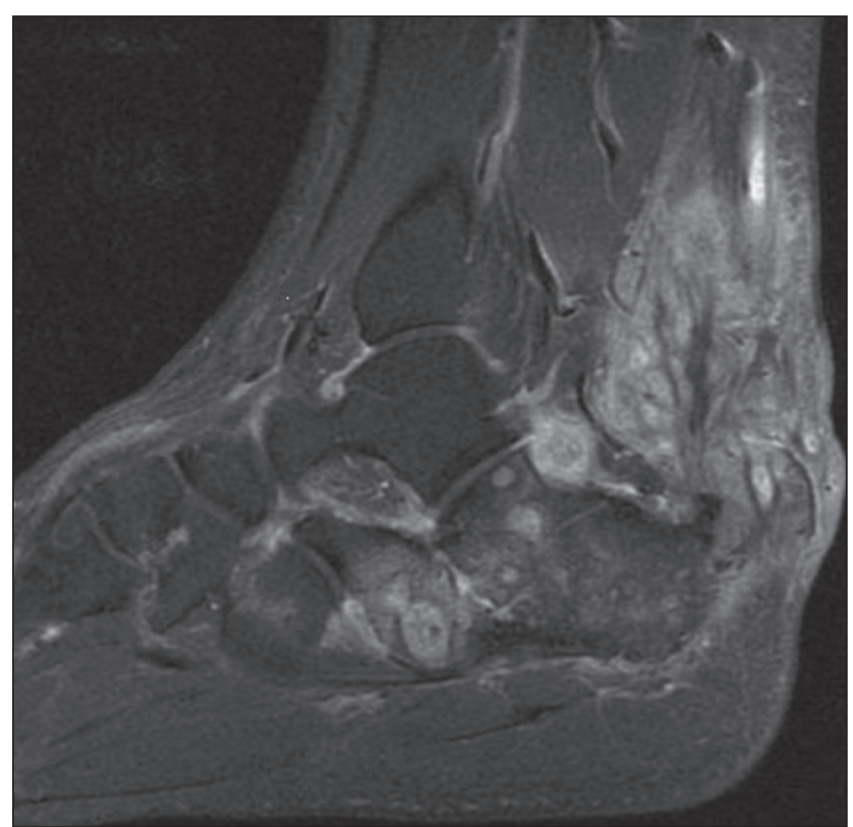

Figure 1) T1-weighted, fat-saturated sagittal magnetic resonance image with gadolinium contrast showing osteomyelitis in the calcaneus with inflammatory tissue adjacent to the calcaneocuboid joint and surrounding the Achilles tendon

cleaned with pulsatile lavage and then irrigated with PHMB 0.2\% solution, which was allowed to dwell for $4 \mathrm{~min}$. Voriconazole $200 \mathrm{mg}$ twice per day was continued.

The patient made excellent progress and voriconazole was discontinued in June 2008. The patient remained well for 3.5 years with good function and no pain in her foot or ankle; she was able to walk in normal shoes for the first time in 10 years. Unfortunately, in late 2011, she complained of pain in the right heel again and clinical examination was consistent with early relapsed disease. She is again being considered for further debridement, PHMB instillation and voriconazole treatment.

\section{Case 2}

An immunocompetent five-year-old Caucasian boy sustained a crush injury to the left hand in October 2007 when a flowerpot fell onto his hand. There were fractures of the thumb, index finger and middle finger, with burst-type wounds, exposing tendons and bone, which were heavily contaminated with soil. The wounds were washed and debrided within $6 \mathrm{~h}$ of injury and empirical intravenous antibiotics were started. The next day, $\mathrm{K}$-wires were used to internally fix the thumb and middle finger, and four days later an external fixator was applied to the index finger. Surgical specimens grew Aspergillus fumigatus, a Fusarium species, Scedosporium prolificans and Trichoderma species. Antifungal treatment was not started because there was no clinical sign of infection at that time.

Thirteen days after the injury, the distal index finger wound began exuding purulent green material. The thumb and middle finger wounds appeared to be healthy. Extensive washout and debridement of the bones of the thumb, index and middle fingers, and removal of the external fixator, was performed. Intravenous amoxicillin-clavulanic acid, voriconazole (two loading doses of $8 \mathrm{mg} / \mathrm{kg}$ every $12 \mathrm{~h}$, followed by oral voriconazole $7 \mathrm{mg} / \mathrm{kg}$ twice per day) and oral terbinafine $125 \mathrm{mg}$ daily were started.

Surgical specimens grew $S$ prolificans and Scedosporium apiospermum. Sensititre MICs for the $S$ prolificans were: amphotericin B $16 \mathrm{mg} / \mathrm{L}$ (resistant), itraconazole $>16 \mathrm{mg} / \mathrm{L}$ (resistant), flucytosine $>64 \mathrm{mg} / \mathrm{L}$ (resistant), voriconazole $4 \mathrm{mg} / \mathrm{L}$ (resistant), posaconazole $>8 \mathrm{mg} / \mathrm{L}$ (resistant) and terbinafine $2 \mathrm{mg} / \mathrm{L}$ (intermediate). The checkerboard method (6) demonstrated synergy for the combination of terbinafine and voriconazole.
Treatment with oral voriconazole and terbinafine was only continued for six weeks; the child's mother stopped treatment after this duration because of blistering lips and photosensitivity. The child also underwent $0.2 \%$ PHMB soaks for several minutes at the time of each dressing change. These began one week after starting voriconazole and terbinafine and occurred three times a week for three weeks. Fungal cultures remained negative and the wounds healed well.

The child later received a skin graft over the distal index finger with a good cosmetic result, although there is poor residual function of the proximal interphalangeal joint. Two years after debridement, there is no evidence of infection.

\section{DISCUSSION}

We describe two immunocompetent patients with fungal osteomyelitis, in whom treatment with a combination of systemic antifungals, extensive surgery and PHMB resulted in cure or prolonged remission.

There are four cases of fungal osteomyelitis reported in the literature in which PHMB had been used as a component of treatment $(2,3,7,8)$. These four cases, together with our two cases, are summarized in Table 1.

S prolificans was the causative organism in three of six cases (50\%) and, in one of these cases, $S$ apiospermum was also cultured. In the other three cases, the causative organisms were F solani, Lecythophora hoffmanii and Scedosporium aurantiacum.

All six patients were apparently immunocompetent. In four cases, trauma preceded the development of fungal osteomyelitis. It is probable that trauma contributed to the development of fungal osteomyelitis in another case (patient 5); and in the case of patient 2, it is likely that $L$ hoffmannii mastoiditis resulted from frequent swimming in a freshwater lake following a tympanoplasty some years previously for tympanic membrane perforation.

The time from initial injury to the diagnosis of fungal osteomyelitis ranged from 13 days to more than a decade. Five of the six patients appear to have been cured or achieved prolonged remission with a median follow-up of 23 months (range 11 to 48 months), and the other patient who initially relapsed (patient 2), was disease-free at the 12-month follow-up after further surgery and prolonged PHMB irrigation.

Fungi are rare causes of osteomyelitis, particularly among immunocompetent patients, in whom fungal osteomyelitis usually follows trauma, surgery or burns rather than resulting from hematogenous dissemination. Other reported causes of fungal osteomyelitis in immunocompetent patients include Apophysomyces elegans (9), Aspergillus species (10), Cryptococcus species (11), Fonsecaea pedrosoi (12) and Sporothrix schenckii (13).

Successful treatment of fungal osteomyelitis in immunocompetent patients usually requires a combination of systemic antifungal treatment and extensive surgical debridement including, at times, amputation. A case report and review of 29 apparently immunocompetent patients with Scedosporium species osteomyelitis or septic arthritis (2) included 19 patients with osteomyelitis. Six of these 19 (32\%) were cured (four received systemic antifungals in combination with surgery and two with knee osteomyelitis received intra-articular amphotericin B alone), nine (47\%) achieved 'improvement' (without cure), three $(16 \%)$ required amputation and one $(5 \%)$ died of an unrelated cause. In a small series involving four immunocompetent patients with Fusarium species osteomyelitis (4), two were cured with systemic or topical amphotericin B and extensive surgical debridement, and two required amputation.

Even with optimal medical and surgical management, the outcome of treatment of immunocompetent patients with fungal osteomyelitis is uncertain. The use of adjunctive treatments is, therefore, of interest; in particular, PHMB has shown promise as a component of the treatment of fungal osteomyelitis.

PHMB (also known as polyhexanide and polyaminopropyl biguanide) is structurally related to hexamidine and was developed in the 
TABLE 1

Cases of fungal osteomyelitis in immunocompetent patients where polyhexamethylene biguanide (PHMB) was used as a component of treatment

\begin{tabular}{|c|c|c|c|c|c|c|c|c|c|c|}
\hline & Age & & & & $\begin{array}{l}\text { Time from } \\
\text { trauma to } \\
\text { surgery + }\end{array}$ & Trea & atment & & & \\
\hline Reference & sex & Predisposing factors & site & organism & + PHMB & Antifungal (duration) & Surgery & Use of PHMB & Outcome & (months) \\
\hline $\begin{array}{l}\text { Steinbach } \\
\text { et al (2), } \\
2003 \\
\text { (patient 1) }\end{array}$ & $5 \mathrm{M}$ & $\begin{array}{l}\text { Trauma - stepped on } \\
\text { nail in chicken coop }\end{array}$ & $\begin{array}{l}\text { Left navicular, } \\
\text { talus, } \\
\text { calcaneus, } \\
\text { cuboid and } \\
\text { cuneiforms }\end{array}$ & $\begin{array}{l}\text { Scedosporium } \\
\text { prolificans }\end{array}$ & 96 days & $\begin{array}{l}\text { Voriconazole and } \\
\text { caspofungin } \\
\text { (6 weeks) }\end{array}$ & Debridement & $\begin{array}{l}\text { Intraoperative irrigation } \\
\text { of surgical site with } \\
0.2 \% \text { PHMB ( } 4 \text { min) }\end{array}$ & Cure & 11 \\
\hline \multirow[t]{2}{*}{$\begin{array}{l}\text { Chang et al } \\
\text { (3), } 2005 \\
\text { (patient 2) }\end{array}$} & $M^{*}$ & $\begin{array}{l}\text { Right tympanoplasty for } \\
\text { tympanic membrane } \\
\text { perforation as a child, } \\
\text { previous grommets (no } \\
\text { longer in situ) }\end{array}$ & Right mastoid & $\begin{array}{l}\text { Lecythophora } \\
\text { hoffmannii }\end{array}$ & $>2$ years & $\begin{array}{l}\text { Itraconazole; } \\
\text { betadine infusions, } \\
\text { hydrogen peroxide/ } \\
\text { topical agents middle } \\
\text { ear space ( } 2 \text { years) }\end{array}$ & $\begin{array}{l}\text { Initial right tympano- } \\
\text { mastoidectomy, later } \\
\text { radical right tympano- } \\
\text { mastoidectomy; then } \\
7 \text { revision procedures }\end{array}$ & $\begin{array}{l}\text { PHMB } 0.02 \% \text { irrigation } \\
\text { mastoid and middle } \\
\text { ear cavity via } \\
\text { perforated catheter - } \\
\text { 'several times a day' } \\
\text { (8 weeks) }\end{array}$ & $\begin{array}{l}\text { Relapse } \\
\text { (2 months } \\
\text { later) }\end{array}$ & - \\
\hline & & & & & & $\begin{array}{l}\text { After relapse: } \\
\text { antifungal treatment } \\
\text { not commented on }\end{array}$ & $\begin{array}{l}\text { After relapse: right } \\
\text { radical meatoplasty, } \\
\text { revision } \\
\text { mastoidectomy, } \\
\text { debridement mastoid, } \\
\text { middle ear }\end{array}$ & $\begin{array}{l}\text { PHMB } 0.02 \% \text { irrigation } \\
\text { right ear cavity daily; } \\
\text { cavity packed with } \\
\text { PHMB-soaked } \\
\text { dressings ('several } \\
\text { months') }\end{array}$ & Cure & $>12$ \\
\hline $\begin{array}{l}\text { Kooijman } \\
\text { et al (7), } \\
2007 \\
\text { (patient 3) }\end{array}$ & $36 \mathrm{M}$ & $\begin{array}{l}\text { Traumatic below-knee } \\
\text { amputation } \\
\text { (agricultural } \\
\text { equipment), wounds } \\
\text { contaminated with } \\
\text { manure }\end{array}$ & Right femur & $\begin{array}{l}\text { Scedosporium } \\
\text { aurantiacum }\end{array}$ & 105 days & $\begin{array}{c}\text { Voriconazole } \\
\text { (12 weeks) }\end{array}$ & $\begin{array}{l}\text { Initial debridement } \\
\text { infected bone. Later } \\
\text { debridement of } \\
\text { abscess in the femoral } \\
\text { stump }\end{array}$ & $\begin{array}{l}\text { Wound soaked in } 0.2 \% \\
\text { PHMB at surgery }\end{array}$ & Cure & 11 \\
\hline $\begin{array}{l}\text { Kesson et al } \\
\text { (8), } 2009 \\
\text { (patient 4) }\end{array}$ & $8 \mathrm{M}$ & $\begin{array}{l}\text { Trauma - compound } \\
\text { fracture right iliac wing } \\
\text { (agricultural } \\
\text { equipment) }\end{array}$ & $\begin{array}{l}\text { Right } \\
\text { acetabulum, } \\
\text { iliac wing, } \\
\text { femoral head }\end{array}$ & S prolificans & 72 days & $\begin{array}{l}\text { Voriconazole } \\
\text { (12 months) } \\
\text { Terbinafine } \\
\text { (14 months) } \\
\text { Hexadecyl- } \\
\text { phospocholine } \\
\text { (13 months) }\end{array}$ & $\begin{array}{l}\text { Debridement bone, joint } \\
\text { capsule, wash out } \\
\text { right hip }\end{array}$ & $\begin{array}{l}\text { PHMB } 0.2 \% \text { lavage of } \\
\text { hip and wound intra- } \\
\text { operatively and } \\
3 \text { times/week } \\
\text { (2 weeks) }\end{array}$ & Cure & 23 \\
\hline $\begin{array}{l}2012 \text { (case } 1 / \\
\text { patient } 5)^{\dagger}\end{array}$ & $35 \mathrm{~F}$ & $\begin{array}{l}\text { Probable trauma - } \\
\text { stepped on needle }\end{array}$ & $\begin{array}{l}\text { Right } \\
\text { calcaneus }\end{array}$ & Fusarium solani & $>10$ years & $\begin{array}{r}\text { Voriconazole } \\
\text { (13 months) }\end{array}$ & Debridement calcaneus & $\begin{array}{l}\text { Intraoperative irrigation } \\
\text { of calcaneus with } \\
\text { PHMB } 0.2 \% \text { ( } 4 \text { min) }\end{array}$ & $\begin{array}{l}\text { Relapse } \\
\text { (4 years } \\
\text { later) }\end{array}$ & 48 \\
\hline $\begin{array}{l}2012 \text { (case } 2 / \\
\text { patient 6) }\end{array}$ & $5 \mathrm{M}$ & $\begin{array}{l}\text { Trauma - compound } \\
\text { fractures fingers } \\
\text { contaminated with soil }\end{array}$ & $\begin{array}{l}\text { Left index and } \\
\text { middle } \\
\text { fingers }\end{array}$ & $\begin{array}{l}\text { S prolificans, } \\
\text { Scedosporium } \\
\text { apiospermum }\end{array}$ & 19 days & $\begin{array}{l}\text { Voriconazole and } \\
\text { terbinafine } \\
\text { (6 weeks) }\end{array}$ & $\begin{array}{l}\text { Debridement thumb } \\
\text { and fingers, removal of } \\
\text { external fixator }\end{array}$ & $\begin{array}{l}\text { Wounds soaked in } \\
0.2 \% \text { PHMB } 3 \text { times/ } \\
\text { week ( } 3 \text { weeks) }\end{array}$ & Cure & 24 \\
\hline
\end{tabular}

${ }^{\star}$ Age reported as 'adolescent'; ${ }^{\dagger}$ Present study. F Female; M Male

1970s for use as an antimicrobial scrub (2). More recently it has been used in wound dressings, as a microbiocide before cataract surgery, a mouthwash, a swimming pool cleaner and as a preservative in contact lens solutions. Topical PHMB has been used for many years to treat Acanthamoeba species keratitis (14) and has become the mainstay of treatment. Its successful use on the ocular surface suggests little toxicity and tissue irritation.

PHMB is believed to exert its activity by the interaction of positively charged biguanide groups with acidic, negatively charged phospholipids in the cytoplasmic membrane of the bacterial and fungal cell wall $(15,16)$. This results in leakage of intracellular contents from the cell, with impairment of function of membrane-associated enzymes (16).

PHMB has good activity against growing fungal hyphae although the effect on conidia is not known (15). Excellent in vitro antifungal activity has been demonstrated. The MIC of PHMB required to inhibit the growth of $90 \%$ of organisms was shown to be $1.56 \mathrm{mg} / \mathrm{L}$ (0.000156\%) for Candida species, $2.4 \mathrm{mg} / \mathrm{L}$ (0.00024\%) for F solani and $6.1 \mathrm{mg} / \mathrm{L}(0.00061 \%)$ for Aspergillus niger (17). There do not appear to be available data on the efficacy of PHMB against Scedosporium species.

To date, there have been no reports of bacterial or fungal resistance to PHMB (18).There are occasional reports of treatment failure when PHMB has been used to treat Acanthamoeba species keratitis; this may occur despite the responsible Acanthamoeba species having retained its in vitro susceptibility to PHMB (14).

The optimal concentration and duration of adjunctive treatment of fungal osteomyelitis with PHMB is unknown. The concentrations of $0.02 \%$ and $0.2 \%$ used in the patients reviewed are significantly higher than the PHMB MIC required to inhibit the growth of $90 \%$ of organisms for the fungal organisms listed above. The treatment durations used in the patients reviewed ranged from as little as 4 min to numerous irrigations over 'several months'.

PHMB is very well tolerated and has a favourable toxicity profile, with little reported skin (18), corneal (14) or mucosal irritation (18). There was no evidence of ototoxicity in patient 2 , despite months of irrigation of the middle ear with PHMB. In addition, it is uncommon for PHMB to cause systemic or contact allergic reactions (18). 


\section{CONCLUSION}

Fungal osteomyelitis in immunocompetent patients is uncommon and often difficult to cure, and those affected often experience significant morbidity. We reviewed six cases of fungal osteomyelitis in immunocompetent patients who were cured, or achieved prolonged remission, with a combination of systemic antifungal treatment, surgery and topical PHMB. The addition of topical PHMB as a safe and well-tolerated adjunct to systemic antifungal treatment and surgery should be considered in patients with fungal osteomyelitis.

ACKNOWLEDGEMENTS: The authors acknowledge Professor John Perfect for his advice (including the suggestion to use PHMB) in the management of our first patient and Dr Sharon Chen for her suggestion to use PHMB for our second patient.

\section{REFERENCES}

1. Berbari EF, Steckelberg JM, Osmon DR. Bone and joint infections: Osteomyelitis. In: Mandell GL, Bennett JE, Dolin R, eds. Principles and Practice of Infectious Diseases. Philadelphia: Churchill Livingstone, 2010:1457-67.

2. Steinbach WJ, Schell WA, Miller JA, Perfect JR. Scedosporium prolificans osteomyelitis in an immunocompetent child treated with voriconazole and caspofungin, as well as locally applied polyhexamethylene biguanide. J Clin Microbiol 2003;41:3981-5.

3. Chang CY, Schell WA, Perfect JR, Hulka GF. Novel use of a swimming pool biocide in the treatment of rare fungal mastoiditis. Laryngoscope 2005;115:1065-9.

4. Sierra-Hoffman M, Paltiyevich-Gibson S, Carpenter JL, Hurley DL. Fusarium osteomyelitis: Case report and review of the literature. Scand J Infect Dis 2005;37:237-40.

5. Cefrulo CL, Leto Barone AA, Jordan K, et al. A multi-disciplinary approach to the management of fungal osteomyelitis: Current concepts in post-traumatic lower extremity reconstruction: A case report. Microsurgery 2012;32:144-7.

6. Swenson JA, Patel JB, Jorgensen JH. Special phenotype methods for detecting antibacterial resistance. In: Versalovic J, Carroll KC, Funke G, Jorgensen JH, Landry ML, Warnock DW, eds. Manual of Clinical Microbiology. Washington DC: ASM Press, 2011:1155-79.
7. Kooijman CM, Kampinga GA, De Hoog GS, Goudswaard WB, Reijnen MM. Successful treatment of Scedosporium aurantiacum osteomyelitis in an immunocompetent patient. Surg Infect 2007;8:605-10.

8. Kesson AM, Bellemore MC, O'Mara TJ, Ellis DH, Sorrell TC. Scedosporium prolificans osteomyelitis in an immunocompetent child treated with a novel agent, hexadecylphospocholine (Miltefosine), in combination with terbinafine and voriconazole: A case report. Clin Infect Dis 2009;48:1257-61.

9. Weinberg WG, Wade BH, Cierney G, Stacy D, Rinaldi MG. Invasive infection due to Apophysomyces elegans in immunocompetent hosts. Clin Infect Dis 1993;17:881-4.

10. Stratov I, Korman TM, Johnson PD. Management of Aspergillus osteomyelitis: Report of failure of liposomal amphotericin B and response to voriconazole in an immunocompetent host and literature review. Eur J Clin Microbiol Infect Dis 2003;22:277-83.

11. Su CT, Chen LK, Tsai YF, Kuo CJ, Lu CL, Chen HY. Disseminated cryptococcosis with pulmonary and marrow involvement mimicking radiological features of malignancy. J Chin Med Assoc 2004;67:89-92.

12. Karuppal R, Kumaran CM, Marthya A, et al. Tibial osteomyelitis due to Fonsecaea pedrosoi in an immunocompetent patient: Case report. J Foot Ankle Surg 2009;48:569-72.

13. Appenzeller S, Amaral TN, Amstalden EM, et al. Sporothrix schenckii infection presenting as monoarthritis: Report of two cases and review of the literature. Clin Rheumatol 2006;25:926-8.

14. Dart JK, Saw VP, Kilvington S. Acanthamoeba keratitis: Diagnosis and treatment update 2009. Am J Ophthalmol 2009;148:487-99.e2.

15. Rebong RA, Santaella RM, Goldhagan BE, et al. Polyhexamethylene biguanide and calcineurin inhibitors as novel anti-fungal treatments for Aspergillus keratitis. Invest Ophthalmol Vis Sci 2011;52:7309-15.

16. McDonnell G, Denver Russell A. Antiseptics and disinfectants: Activity, action and resistance. Clin Microbiol Rev 1999;12:147-79.

17. Messick CR, Pendland SL, Moshirfar M, et al. In vitro activity of polyhexamethylene biguanide (PHMB) against fungal isolates associated with infective keratitis. J Antimicrob Chemother 1999;44:297-8.

18. Hubner NO, Kramer A. Review on the efficacy, safety and clinical applications of polihexanide, a modern wound antiseptic. Skin Pharmacol Physiol 2010;23(Suppl 1):17-27. 


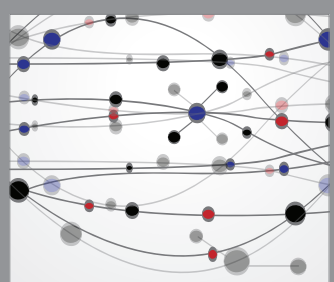

The Scientific World Journal
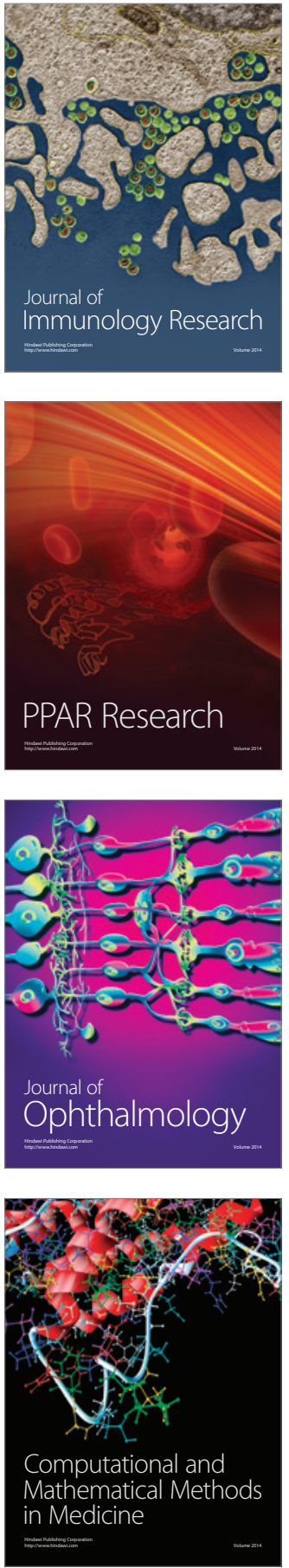

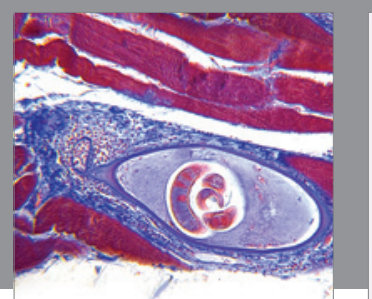

Gastroenterology Research and Practice

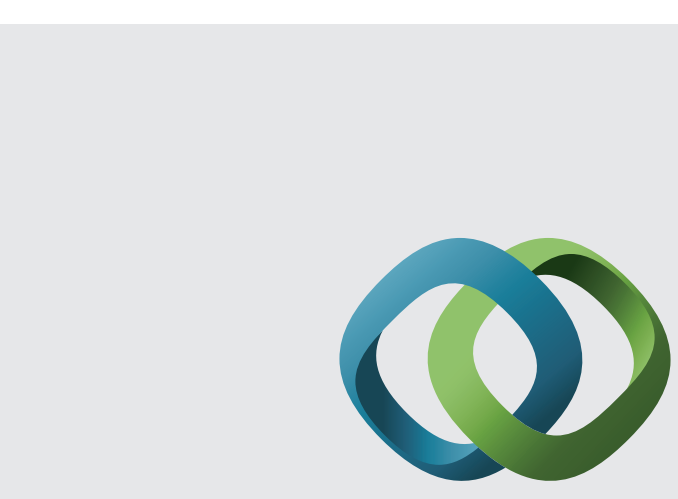

\section{Hindawi}

Submit your manuscripts at

http://www.hindawi.com
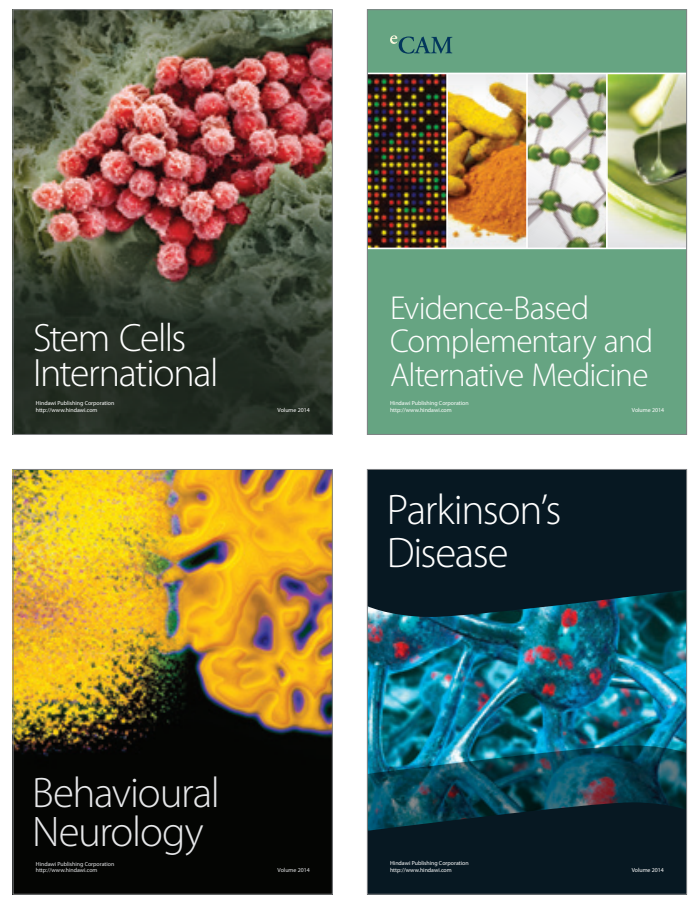
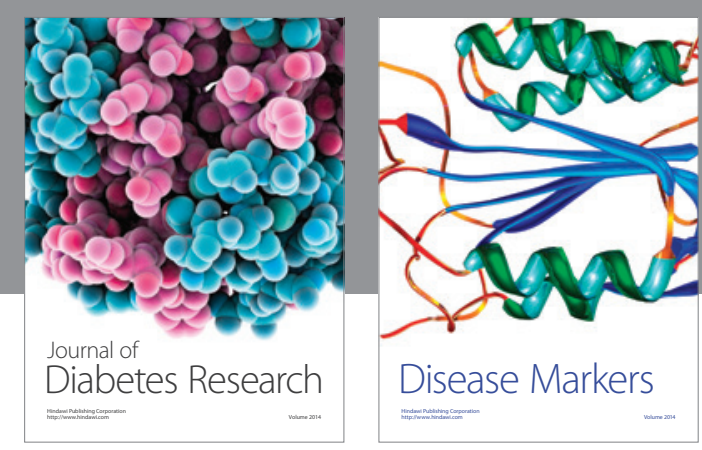

Disease Markers
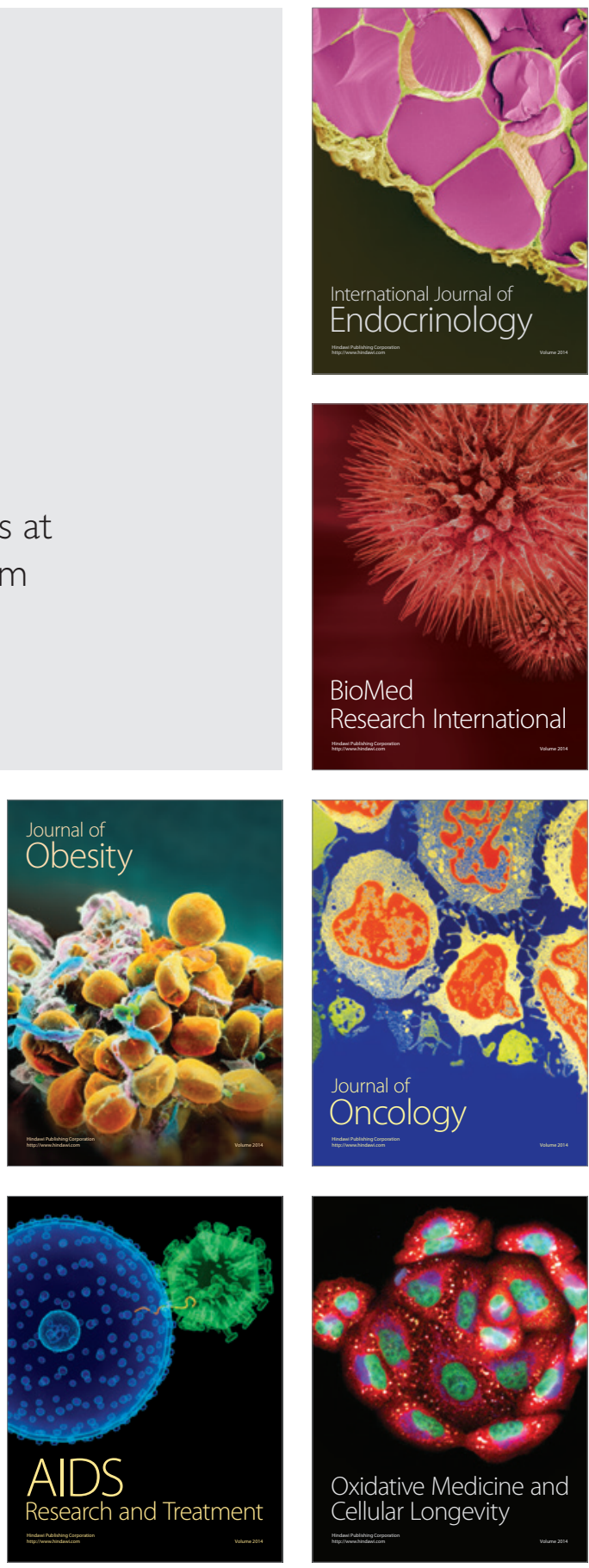